\title{
Исходный материал для селекции сортов ярового ячменя, толерантных к абиотическим стрессам
}

Зайцева И.Ю. *, м.н.с., аспирант; Кокина Л.П., к.с.-х.н., с.н.с. Федеральный аграрный научный иенттр Северо-Востока имени Н.В. Рудницкого, г. Киров, Российская Федерачия.

*e-mail: irina-zajjceva30@rambler.ru

Обеспечение устойчивого роста величины и качества урожая сортов ячменя связано с повышением их экологической устойчивости за счет селекиии. Ведущая роль в успешном решении этой задачи принадлежит научнообоснованному подбору генетически разнообразного исходного материала. Проведена оценка 28 коллекционных образиов различного эколого-географического происхождения на устойчивость к засухе и алюмокислому стресс. Для дальнейшей селекиионной работы выделены образиьы: Бионик, Одесский 115, Полярный 14, Новичок, Сябра, NCL 95098, местный сорт из Китая (к2929), Haxby, Rodos, Наран, Казьминский, Bonita, Danuta и 752 A.

Ключевые слова: ячмень, коллекция, корни, засухоустойчивость, алюмоустойчиовсть.

\section{Initial material for breeding spring barley cultivars tolerant to abiotic stresses}

Zaytseva I.Yu., Associate Researcher, Post-graduate ; Kokina L.P., PhD in Agriculture, Senior Researcher; Federal Agricultural Research Center of the NorthEast name N.V. Rudnitsky, Kirov, Russian Federation.

e-mail: irina-zajjceva30@rambler.ru

Sustainable growth in the value and quality of barley's yield is linked to improve its environmental resistance through breeding. A science-based selection of genetically diverse initial material plays a leading role in the success of this task. Twenty-eight collection samples of different ecological-geographical origin were evaluated for resistance to drought and aluminum-acid stress. For further breeding work next samples were selected: Bionic, Odessky 115, Polarny 14, Novichok, Syabra, NCL 95098, local variety from China (k-2929), Haxby, Rodos, Naran, Kazminsky, Bonita, Danuta, and 752A.

Key words: sample, collection, roots, drought resistance, aluminum resistance.

Увеличение урожайности является одной из наиболее важных задач в селекции сельскохозяйственных культур, в том числе и ячменя. Потенциальная возможность сорта дать реальный урожай зависит от уровня устойчивости 
сорта к стрессовым экологическим факторам окружающей среды [2].

В настоящее время к категории наиболее сложных фитоэкологических проблем относится эдафический стресс, обусловленный ионной токсичностью алюминия и марганца, связанных с величиной $\mathrm{pH}$, т.е. почвенной кислотностью [12]. Волго-Вятский регион считается зоной достаточного увлажнения, но для него характерно неравномерное выпадение осадков в течение вегетационного периода, которое ограничивает рост сельскохозяйственных культур и сопровождается значительными потерями урожая [5]. Эти абиотические стрессы нарушают происходящие в растениях физиологические процессы, что ведет к ухудшению качества зерна (семян) и снижению урожайности. В связи с этим обеспечение устойчивого роста величины и качества урожая сельскохозяйственных культур, в том числе ячменя, связано с повышением их экологической устойчивости методами селекции [1].

Цель исследований: изучение генофонда ячменя различного эколого-географического происхождения и выделение источников алюмо- и засухоустойчивости для создания толерантных к абиотическим стрессам высокопродуктивных сортов ячменя, пригодных для эффективного использования в Кировской области.

Материалы и методика. Экспериментальная работа проводилась в ФГБНУ ФАНЦ Северо-Востока (г. Киров). Объектом исследований являлись 28 образцов ярового ячменя различного эколого-географического происхождения. Оценку сортов к эдафическим стрессам проводили согласно методикам лабораторной оценки алюмоустойчивости зерновых культур [6]. Засухоустойчивость ярового ячменя изучали по лабораторной методике ВИР [3].

Результаты. Для прогнозирования отбора форм с высокими адаптивными свойствами необходима оценка по комплексу биологически ценных признаков на разных этапах онтогенеза. Однако большое значение имеет изучение первичной корневой системы и надземных органов, изменчивость которых может характеризовать степень устойчивости популяции, способность ее противостоять неблагоприятным факторам среды $[9,11]$.

Показатель ИДК изменялся от 56,1 \% (Cooper) до 110,3 \% (Haxby). По уровню алюмоустойчивости (по величине ИДК согласно [13]) изучаемые образцы были распределены на две группы: умеренно устойчивые - сорта Crusades, Cooper, Sultan и Filippa и устойчивые - все остальные сорта. У сортов Haxby (ИДК=110,3 \%) и Полярный 14 (ИДК=102,1 \%) был отмечен стимулирующий эффект алюминия на рост корневой системы (ИДК>100 \%), что ранее наблюдалось рядом исследователей $[4,6,12]$. В наших исследованиях не установлено тесной корреляционной взаимосвязи между ИДК и урожайностью сортов в полевых условиях (r=0,052), поэтому в дополнение к этому показателю, как рекомендует [7], использовали еще один - RSR.

Показатель относительного соотношения RSR (изменение показателя 
под влиянием стресса) при оценке устойчивости сортов к повышенному содержанию ионов алюминия изменялся от снижения на 26,8 \% (752А) до увеличения на 49,6 \% (Бионик). Среди изученных сортов по этому показателю выделились Бионик, Mentor, Orthega, NCL 95098, местные сорта из Китая (к2929 и к-2930), Одесский 115, Сябра, Полярный 14, обладавшие также высоким ИДК (табл. 1).

Таблица 1 - Алюмоустойчивые сорта ячменя

\begin{tabular}{|l|c|c|c|c|}
\hline \multicolumn{1}{|c|}{ Сорт } & $\begin{array}{c}\text { Отклоне- } \\
\text { ние ИДК, } \\
\%\end{array}$ & $\begin{array}{c}\text { Относи- } \\
\text { тельная } \\
\text { RSR, \% }\end{array}$ & $\begin{array}{c}\text { Отклонение } \\
\text { RSR, \% }\end{array}$ & $\begin{array}{c}\text { Суммарный } \\
\text { индекс } \\
\text { устойчивости }\end{array}$ \\
\hline Белгородский 100 & 24,2 & 83,7 & 16,3 & 40,5 \\
\hline Новичок & 8,3 & 90,3 & 9,7 & 18,0 \\
\hline Бионик & 14,3 & 149,6 & 49,6 & 63,9 \\
\hline Меntor & 15,1 & 115,5 & 15,5 & 30,6 \\
\hline Danuta & 8,3 & 115,7 & 15,7 & 24,0 \\
\hline NCL 95098 & 3,6 & 108,4 & 8,4 & 12,0 \\
\hline Haxby & 10,3 & 92,8 & 7,2 & 17,5 \\
\hline Местный сорт (к-2929) & 12,6 & 112,7 & 12,7 & 25,3 \\
\hline Местный сорт (к-2930) & 2,3 & 107,5 & 7,5 & 9,8 \\
\hline Одесский 115 & 14,9 & 101,4 & 1,4 & 16,3 \\
\hline Сябра & 11,5 & 102,8 & 2,8 & 14,3 \\
\hline Rодоз & 7,7 & 99,1 & 0,9 & 8,5 \\
\hline Полярный 14 & 2,1 & 103 & 3,0 & 5,1 \\
\hline Наран & 8,2 & 89,2 & 10,8 & 19,0 \\
\hline Казьминский & 5,6 & 89,3 & 10,7 & 16,3 \\
\hline
\end{tabular}

Так как отдельные генотипы используют различные механизмы устойчивости в разной степени, логичнее использовать сразу несколько параметров для оценки уровня устойчивости сорта к стрессовому воздействию. С другой стороны, оценить их вклад в интегральную устойчивость по абсолютным значениям несколько затруднительно, поэтому, согласно [9], нами для принятия решения использовались относительные уровни развития того или иного признака.

Таким образом, на основе выше изложенного из сортов устойчивых к алюмокислому стрессу по обоим показателям (ИДК и RSR) выделялись NCL 95098, местный сорт из Китая (к-2929), Одесский 115, Сябра, Полярный 14. Они обладали наименьшим суммарным индексом устойчивости, а значит и отклонениями ИДК и RSR, поэтому физиологические процессы, протекаю- 
щие в растениях данных сортов при воздействии алюмокислого стресса, более стабильны. Кроме уже перечисленных образцов, к устойчивым можно отнести сорта Новичок, Нaxby, Rodos, Наран и Казьминский, также отличавшихся наименьшим суммарным индексом устойчивости.

По устойчивости к засухе (по способности прорастать в растворе осмотика ПЭГ-600) все изученные сорта разделились на три группы: среднеустойчивые, с устойчивостью выше средней и высокоустойчивые.

Самой высокой всхожестью в стрессовых условиях характеризовался сорт Новичок (91 \%). Также по уровню всхожести к высокоустойчивым к засухе можно отнести сорта Бионик $(84,4 \%)$, Orthega $(81,1 \%)$, Bonita (82,2\%), Ci 11084 (83,3\%), Makbo (80,0\%), Наран (88,8\%). У сортов Crusades (55,6 \%), Sultan (50 \%), Ментор (48,9\%), Mie (48,9\%), характеризующихся, как среднеустойчивые, была самая низкая всхожесть.

При оценке сортов на засухоустойчивость RSR варьировал от снижения на 51,4 \% у сорта Ментор до увеличения на 459,1 \% у сорта Filippa. Наибольшей относительной RSR характеризовались образцы, представленные в таблице 2. Кроме них, по этому параметру выделились сорта Новичок, Crusades, Cooper, Orthega, Danuta, Bonita, местный сорт из Афганистана (к5983), местный сорт из Китая (к-2929), Makbo, Одесский 115, Mie, Rodos, Полярный 14.

Таблица 2 - Сорта с высокой относительной RSR

\begin{tabular}{|l|c|c|}
\hline \multicolumn{1}{|c|}{ Сорт } & Относительная RSR, \% & Отклонение RSR, \% \\
\hline Белгородский 100 & 203,0 & 103,0 \\
\hline Sultan & 223,2 & 123,1 \\
\hline Filippa & 559,1 & 459,1 \\
\hline Ci 11084 Lan & 289,2 & 189,2 \\
\hline Haxby & 406,5 & 306,5 \\
\hline Mестный сорт (к-2930) & 258,0 & 158,0 \\
\hline Сябра & 294,7 & 194,7 \\
\hline Наран & 217,0 & 117,0 \\
\hline Щедрый & 254,4 & 154,4 \\
\hline
\end{tabular}

Среди названных выше образцов наибольшей толерантностью к засухе характеризовались сорта Новичок, Orthega, Bonita, Ci 11084 Lan и Наран, сочетавшие высокую всхожесть и относительную RSR. Однако из этих образцов лишь сорт Bonita имел наименьшее отклонение RSR, что характеризует его как более устойчивого к засухе по сравнению с остальными. Также к засухоустойчивым можно отнести сорта не обладавшие высокой $\mathrm{RSR}$, но имевшие наименьшее отклонение этого показателя и хорошую всхожесть: Бионик, Danuta, 752A, NCL 95098, Одесский 115, Rodos, Казьминский. Одним из наименьших отклонений RSR отличался сорт Mie, но из-за 
низкой всхожести в стрессовых условиях мы не можем отнести его к засухоустойчивым.

Выводы. В качестве исходного материала для создания алюмоустойчивых сортов рекомендуется использовать коллекционные образцы: NCL 95098, местный сорт из Китая (к-2929), Одесский 115, Сябра, Полярный 14, Новичок, Нaxby, Rodos, Наран и Казьминский; для создания засухоустойчивых сортов - Bonita, Бионик, Danuta, 752A, NCL 95098, Одесский 115, Rodos и Казьминский.

\section{Список литературы}

1. Анисимова Н.Н., Ионова Е.В. Элементы структуры урожая сортов ярового ячменя и их вклад в формирование высокой продуктивности растений // Зерновое хозяйство России. Аграрный научный центр «Донской» (Зерноград). 2016. №5. С. 40-43.

2. Баталова Г.А. Овес в Волго-Вятском регионе. - Киров: ООО «Орма», 2013. $288 \mathrm{c}$.

3. Диагностика устойчивости растений к стрессовым воздействиям: методическое руководство / Под ред. Г.В. Удовенко. - Л.: ВИР, 1988. - 227 с.

4. Климашевский, Э.Л. Генетический аспект минерального питания растений. М.: Агропромиздат. 1991. - 420 с.

5. Кокина Л.П., Щенникова И.Н., Зайцева И.Ю. Оценка коллекционных образцов ячменя на устойчивость к осмотическому стрессу // Аграрная наука Евро-Северо-Востока. 2018. №5 (66).

6. Лисицын Е.М. Методика лабораторной оценки алюмоустойчивости зерновых культур // Доклады РАСХН. 2003. №3. С. 5-7.

7. Лисицын Е.М. Показатели развития корневых систем в эдафической селекции ячменя // Зернобобовые и крупяные культуры. 2018. №2 (26).

8. Лисицын Е.M. Физиологические параметры корневых систем в селекции зерновых культур на абиотическую устойчивость // Вестник Марийского государственного университета. Серия «Сельскохозяйственный науки. Экономические науки». 2018. T. 4. № 3. С. 7-44.

9. Пакуль, В. Н. Источники ярового ячменя по засухоустойчивости в условиях лесостепи Западной Сибири / В.Н. Пакуль, С.В. Мартынова, Д.Е. Андросов // Международный научно-исследовательский журнал. 2016. № 2 (44) Часть 3. С. 102-106.

10. Щенникова И.Н., Шуплецова О.Н., Бутакова О.И. Оценка сортов ярового ячменя на кислотоустоустойчивость $\left(\mathrm{A} 1^{+}\right) / /$Генетические ресурсы ржи, ячменя и овса / Труды по прикладной ботанике, генетике и селекции / С-Пб.: ВИР, 2009. Т. 165. С. 179-182.

11. Яковлева О.В., Капешинский А.М. Толерантность ячменя к токсичным ионам алюминия в условиях почвенной культуры // Труды по прикладной ботанике, генетике и селекции. 2011; 168: 54-64.

12. Яковлева О.В. Фитотоксичность ионов алюминия // Труды по прикладной ботанике, генетике и селекции. 2018; 179(3): 315-331.

13. Navacode S., Weidner A., Varshney R.K. Lohwasser U., Scholz U., Roder M.S., Borner A. A genetic analysis of aluminium tolerance in cereais // Agris Conspec Sci. 2010. V. 75. No. 4. P. 191-196. 